\title{
Penyuluhan hukum terkait partisipasi masyarakat dalam proses pembentukan peraturan desa di Desa Koto Masjid Kecamatan XIII Koto Kampar Kabupaten Kampar
}

\author{
Dessy Artina*, Mexsasai Indra, Emilda Firdaus, Gusliana HB, Zulwisman, Muhammad A Rauf, \\ \& Zainul Akmal
}

Fakultas Hukum, Universitas Riau

*echie_chay@yahoo.co.id

\begin{abstract}
Abstrak. Setelah disahkannya Undang-Undang Nomor 6 Tahun 2014 tentang Desa pada tanggal 15 Januari 2014, Republik Indonesia kini memiliki undang-undang yang khusus mengatur tentang penyelenggaraan pemerintahan desa. Bagian sangat penting adalah adanya pengaturan tentang Peraturan Desa. Peraturan desa ditetapkan oleh kepala desa setelah mendapat persetujuan bersama Badan Permusyawaratan Desa. Dalam proses pembentukan peraturan desa dibutuhkan partisipasi masyarakat, agar output dari peraturan desa dapat memenuhi aspek kebutuhan masyarakat setempat yang disampaikan melalui Badan Permusyawaratan Desa. Aspirasi masyarakat setempat berupa masukan dan sumbang pemikiran lebih efektif, karena keluhan dan pendapat masyarakat menjadi pertimbangan dalam pengambilan keputusan. Terkait hal itu rumusan masalah dalam pengabdian ini adalah bagaimanakah partisipasi masyarakat dalam proses pembentukan Peraturan Desa di Desa Koto Masjid Kecamatan XIII Koto Kampar Kabupaten Kampar? Masih sangat banyak penyelenggara desa (Kepala Desa dan Badan Permusyawaratan Desa) dan masyarakat desa yang belum memiliki pengetahuan dan keahlian dalam bidang peraturan perundang-undangan. Hal ini berpotensi memengaruhi kesuksesan implementasi Undang-Undang tentang Desa, dan bahkan tidak menutup kemungkinan akan menimbulkan kekisruhan hukum, antara lain yaitu terjadi pertentangan dan tumpang-tindih peraturan perundang-undangan. Sehingga untuk kedepanya diperlukan pengetahuan-pengetahuan mengenai pembentukan peraturan perundang-undangan yang mampu mendorong masyarakat untuk berpartisipasi dalam pembentukan peraturan desa, mewujudkan Peraturan Desa yang aspiratif, responsif, taat asas, selaras, dan serasi secara vertikal dan horizontal dalam rangka pembangunan sistem hukum nasional berdasarkan Undang-Undang Dasar Negara Republik Indonesia Tahun 1945, dan menghasilkan Rancangan Peraturan Perundang-undangan yang dapat dipertanggungjawabkan secara filosofis, yuridis, dan sosiologis. Pengetahuan-pengetahuan tersebut dapat diperoleh melalui penyuluhan hukum, khususnya penyuluhan hukum terkait partisipasi masyarakat dalam proses pembentukan peraturan desa di Desa Koto Masjid, Kecamatan XIII Koto Kampar, Kabupaten Kampar.
\end{abstract}

Kata kunci: partisipasi masyarakat; peraturan desa; desa koto masjid

\begin{abstract}
After the enactment of Law Number 6 of 2014 concerning Villages on 15 January 2014, the Republic of Indonesia now has laws specifically regulating the administration of village governance. A very important part is the arrangement of village regulations. Village regulations are set by the village head after obtaining approval with the Village Consultative Body. In the process of establishing village regulations, community participation is needed, so that the output of village regulations can fulfill aspects of local community needs that are conveyed through the Village Consultative Body. The aspirations of the local community in the form of input and contribution ideas are more effective, because community complaints and opinions are taken into consideration in decision making. Related to this matter, the formulation of the problem in this study is how is community participation in the process of establishing Village Regulations in Koto Masjid Village, District XIII, Koto Kampar, Kampar Regency? There are still very many village organizers (Village Heads and Village Consultative Bodies) and village communities who do not yet have the knowledge and expertise in the field of legislation. This has the potential to affect the success of the implementation of the Law on Villages, and even does not rule out the possibility of creating legal chaos, among others, the occurrence of conflicts and overlapping laws and regulations. So that in the future knowledge of the establishment of legislation is needed which is able to encourage people to participate in the formation of village regulations, realize Village Regulations that are aspirational, responsive, obedient, harmonious and harmonious vertically and horizontally in the framework of developing national legal systems based on The 1945 Constitution of the Republic of Indonesia, and produced a Draft Law and Regulations that could be accounted for philosophically, juridically and sociologically.
\end{abstract}


Knowledge can be obtained through legal counseling, especially legal counseling related to community participation in the process of establishing village regulations in Koto Masjid Village, District XIII Koto Kampar, Kampar District.

Keywords: community participation; village regulations; koto masjid village

To cite this article: Artina. D., M. Indra, E. Firdaus, Gusliana HB, Zulwisman, M. A. Rauf, \& Z. Akmal. 2019.

Penyuluhan hukum terkait partisipasi masyarakat dalam proses pembentukan peraturan desa di Desa Koto Masjid,

Kecamatan XIII Koto Kampar, Kabupaten Kampar. Unri Conference Series: Community Engagement 1: 590-597

https://doi.org/10.31258/unricsce.1.590-597

(C) 2019 Authors

Peer-review under responsibility of the organizing committee of Seminar Nasional Pemberdayaan Masyarakat 2019

\section{PENDAHULUAN}

Penyusunan peraturan perundang-undangan bukan saja mengacu pada tujuannya untuk melindungi dan mengayomi masyarakat, tetapi juga harus berpatokan pada hierarki peraturan perundang-undangan, salah satunya adalah asas lex generalis derogad lex specialis yaitu peraturan bersifat umum dilemahkan oleh peraturan bersifat khusus. Bila ada pertentangan peraturan secara hierarki digunakan asas lex superiori derogad lex inferiori yaitu peraturan yang lebih tinggi melemahkan peraturan yang lebih rendah. Maka dari itu, asas hukum diharapkan bersifat luwes agar tidak terjadi masalah yang berkepanjangan akibat dari pertentangan antara peraturan yang bersifat umum dan khusus. Masyarakat dan aparatur pemerintah diharapkan menyadari bahwa peraturan hukum baik yang bersifat umum maupun khusus dibuat demi menciptakan ketertiban dan kesejahteraan bersama (Agustyarna, 2014).

Salah satu bentuk peraturan perundang-undangan yang dimaksud adalah peraturan desa. Keberadaan peraturan desa sudah diatur dalam Undang-Undang tentang Pemerintahan Daerah yaitu Nomor 32 Tahun 2004, namun belum memberikan definisi atau batasan tentang apa yang dimaksud dengan peraturan desa. Rumusan tentang peraturan desa ditegaskan dalam Undang-undang Nomor 10 Tahun 2004 tentang Pembentukan Peraturan Perundang-undangan, yaitu peraturan perundang-undangan yang dibuat oleh badan perwakilan desa atau nama lainnya bersama dengan kepala desa atau nama lainnya. Definisi ini juga yang digunakan oleh Undang-Undang Nomor 6 Tahun 2014 yang merupakan pengaturan lebih lanjut tentang Desa (Agustyarna, 2014).

Peraturan desa ditetapkan oleh kepala desa setelah mendapat persetujuan bersama Badan Permusyawaratan Desa, dalam menyelenggarakan otonomi desa. Peraturan desa dilarang bertentangan dengan kepentingan umum dan atau peraturan perundang-undangan yang lebih tinggi. Dalam proses pembuatan peraturan desa dibutuhkan partisipasi masyarakat, agar output dari peraturan desa dapat memenuhi aspek kebutuhan masyarakat setempat yang disampaikan melalui Badan Permusyawaratan Desa, supaya keberlakuan hukum dan dapat dilaksanakan sesuai tujuan pembentukannya. Aspirasi masyarakat setempat berupa masukan dan sumbang pemikiran dalam perumusan substansi pengaturan peraturan desa lebih efektif posisinya dalam mempengaruhi para pengambil kebijakan kerena keluhan dan pendapat masyarakat acapkali menjadi pertimbangan dalam pengambilan keputusan (Sofyan, 2014).

Desa sebagai salah satu bentuk pemerintahan di daerah dan sebagai bagian dari Negara Kesatuan Republik Indonesia, memiliki status dan kedudukan hukum, serta memiliki tatanan pemerintahan yang otonom dan mandiri dalam menjalankan segala urusan rumah tangganya. Ada bermacam-macam urusan yang diselenggarakan oleh pemerintahan desa, dan urusan pemerintahan desa yang dilaksanakan saat ini tidak lagi semata-mata hanya mengurus kepentingan tradisional, tetapi harus menjadi bagian integral dari Negara Kesatuan Republik Indonesia dalam menjalankan pemerintahan sesuai dengan perkembangan jaman (Astawa, 2009).

Salah satu unsur penting yang harus dimiliki agar desa dapat menjalankan fungsi pemerintahan dan pelayanannya adalah dengan mengatur kehidupan masyarakat desa yang bersangkutan. Pengaturan dapat dilakukan dengan membentuk peraturan perundang-undangan baik di pusat maupun daerah termasuk desa, dan juga dengan menghormati atau mengakui aturan yang sudah ada dalam masyarakat desa tersebut. Pada tatanan 
pemerintahan desa, maka peraturan yang dapat dibuat oleh desa adalah dalam bentuk Peraturan Desa (selanjutnya disebut Perdes) maupun Peraturan bersama Kepala Desa dan Peraturan Kepala Desa (Pasal 69 ayat (1) UU Nomor 6 Tahun 2014 tentang Desa). Peraturan Desa menurut Pasal 1 angka 7 UU Nomor 6 Tahun 2014 adalah peraturan perundang-undangan yang ditetapkan oleh Kepala Desa setelah dibahas dan disepakati bersama Badan Permusyawaratan Desa (BPD). Dengan demikian maka Perdes adalah merupakan salah satu jenis peraturan perundang-undangan, yang dibentuk dalam rangka penyelenggaraan pemerintahan desa (Suantra, 2016).

Peraturan Desa mempunyai fungsi yang sangat penting yakni, merupakan manifestasi dari nilai-nilai yang ada di dalam masyarakat dan merupakan cerminan dari masyarakat desa yang bersangkutan. Karena itu fungsi Peraturan Desa sebagaimana fungsi hukum pada umumnya adalah sebagai sarana untuk menegakkan atau mewujudkan keadilan bagi masyarakat desa yang bersangkutan dan juga sebagai upaya dalam pencapaian tujuan negara sebagaimana diamanatkan dalam Pembukaan UUD Tahun 1945. Peraturan Desa juga dibutuhkan guna terlaksananya sinergitas pemerintahan desa sebagai pemerintah yang melaksanakan tugastugas Negara, dan juga dapat melakukan adjusmen kekuasaan dengan masyarakat. Peraturan desa bermanfaat sebagai pedoman kerja bagi semua pihak, dalam menyelenggarakan kegiatan di Desa. Jadi, peraturan desa tersebut sangat penting keberadaannya di dalam membangun dan mengurus desa, membatasi kekuasaan (kewenangan dan intervensi) pemerintah daerah dan pusat, serta melindungi hak-hak prakarsa masyarakat desa, menjamin kebebasan masyarakat desa. Selain itu penetapan Peraturan Desa dipandang perlu sebagai upaya dari pemerintah di tingkat bawah untuk mengubah perilaku masyarakat (Suantra, 2016). Maka karena alasan perlu dilakukannya penyuluhan hukum mengenai pentingya partisipasi masyarakat dalam pembentukan Peraturan Desa khususnya di Desa Koto Masjid Kecamatan XIII Koto Kampar Kabupaten Kampar. Serta dengan dilaksanakannya kegiatan penyuluhan ini diharapkan memberi perubahan bagi individu/masyarakat Desa Koto Masjid maupun institusi baik jangka pendek maupun jangka panjang.

Proses penyusunan perundang-undangan meliputi berbagai tingkat penyelesaian, seperti tingkat persiapan, penetapan, pelaksanaan, penilaian dan pemaduan kembali produk yang sudah jadi. Seorang perancang peraturan perundang-undangan diharuskan mempunyai pengetahuan yang memadai tentang keadaan sosial budaya, sosial ekonomi dan sosial politik masyarakat. Proses penetapan peraturan perundang-undangan memerlukan pengetahuan dan pemahaman yang baik tentang prosedur dan tata cara yang digariskan dalam sistem tata pemerintahan yang berlaku. Fenomena yang terjadi sekarang adalah banyak peraturan perundangan yang tidak sesuai dengan kondisi masyarakat (Huda, 2011). Pengabdian ini bertujuan untuk memberikan masukan agar masyarakat ikut berpartisipasi dalam proses pembentukan Peraturan Desa di Desa Koto Masjid Kecamatan XIII Koto Kampar Kabupaten Kampar dan memberikan pengetahuan kepada masyarakat urgensi partisipasi masyarakat dalam pembentukan Peraturan Desa.

\section{Masalah}

Mengacu pada latar belakang di atas mengenai partisipasi masyarakat dalam proses pembentukan peraturan desa maka rumusan masalah yaitu: bagaimanakah partisipasi masyarakat dalam proses pembentukan Peraturan Desa di Desa Koto Masjid Kecamatan XIII Koto Kampar Kabupaten Kampar?

\section{METODE PENERAPAN}

\section{Jenis Penelitian}

Pengabdian ini menggunakan jenis hukum sosiologis atau empiris atau ke lapangan yaitu suatu penulisan yang menggunakan asumsi masyarakat dalam mencari fakta-fakta yang terjadi di lapangan untuk menjawab suatu permasalahan yang ada. Dalam penulisan ini melakukan observasi langsung mengenai Partisipasi Masyarakat Dalam Proses Pembentukan Peraturan Desa Di Desa Koto Masjid, Kecamatan XIII Koto Kampar, Kabupaten Kampar.

\section{Lokasi Pengabdian}

Lokasi pengabdian ini adalah di Desa Koto Masjid, Kecamatan XIII Koto Kampar, Kabupaten Kampar.

\section{Responden}

a. Pemerintah Desa Koto Masjid, Kecamatan XIII Koto Kampar, Kabupaten Kampar;

b. Masyarakat Desa Koto Masjid, Kecamatan XIII Koto Kampar, Kabupaten Kampar.

\section{Sumber Data}

Data yang akan digunakan dalam pengabdian ini adalah: 
a. Data primer adalah data yang diperoleh secara langsung dari responden dengan menggunakan alat pengumpulan data berupa wawancara atau dialog saat melakukan penyuluhan hukum.

b. Data sekunder adalah data yang diperoleh dari peraturan perundang-undangan dan literatur-literatur yang berhubungan dengan masalah pokok dari pengabdian ini.

c. Data tertier adalah data yang diperoleh melalui kamus, ensiklopedi dan sebagainya yang berfungsi untuk mendukung data primer dan sekunder.

\section{Teknik Pengumpulan Data}

Adapun teknik pengumpulan data yang penulis gunakan sebagai berikut:

a. Wawancara

Yaitu mengadakan proses tanya jawab langsung atau dialog kepada responden dengan pertanyaanpertanyaan non struktur terkait permasalahan pada saat melakukan penyuluhan hukum.

b. Kajian Kepustakaan

Yaitu untuk memperlengkap data yang dibutuhkan dalam pengabdian ini, penulis melakukan pengumpulan data dengan literatur kepustakaan yang mempunyai hubungan logis dengan permasalahan. Hal ini dilakukan untuk mencari data sekunder sebagai pendukung terhadap data primer.

\section{Teknik Analisis Data}

Data yang telah dikumpulkan akan dianalisis secara kualitatif dengan menggunakan uraian kalimat untuk menjelaskan hubungan antara teori yang ada dengan kenyataan yang ada di lapangan. Analisis data dilakukan dengan tahap sebagai berikut:

a. Tahap Persiapan

Pada tahap ini mempersiapkan data-data yang diperlukan untuk melakukan pengabdian kepada masyarakat seperti melaksanakan observasi ke lokasi pengabdian atau penyluhan hukum, mempersiapkan surat izin, dan mempersiapkan bahan untuk pengabdian kepada masyarakat atau bahan penyuluhan hukum.

b. Tahap Pelaksanaan

Pada tahap ini melakukan pengabdian kepada masyarakat dalam bentuk penyluhan hukum dan juga melakukan dialog langsung dengan aparat desa.

c. Tahap Penyelesaian

Pada tahap ini dilakukan berbagai kegiatan yaitu menganalisis data hasil kegiatan dilapangan dengan mengelompokkan serta menghubungkan aspek-aspek yang berkaitan kemudian dilanjutkan dengan penulisan laporan. Setelah itu dilakukan penyempurnaan laporan akhir.

\section{Waktu dan Durasi Kegiatan}

Kegiatan Pengabdian kepada masyarakat dalam bentuk Penyuluhan Hukum dilaksanakan pada tanggal 25 Juni 2019 dari Pukul 09 Wib sampai Pukul 12 WIB.

\section{HASIL DAN KETERCAPAIAN SASARAN}

\section{Partisipasi Masyarkat}

Pemerintah mengupayakan masyarakat sebagai pusat aktifitas pembangunan, pernyataan ini dapat dibuktikan dengan diterapkannya Undang-Undang Nomor 9 Tahun 2015 tentang Perubahan Kedua Atas Undang-Undang Nomor 23 Tahun 2014 tentang Pemerintahan Daerah. Dimana setiap daerah diberi kesempatan seluas-luasnya untuk mengurus rumah tangganya sendiri, setiap daerah diberi peluang untuk menggali segenap potensi sumber daya manusia dan sumber daya alam yang ada dalam wilayahnya agar dapat dimanfaatkakn secara optimal sehingga tercapai perkembangan dan kemajuan daerah.

Pasal 2 ayat (4) Undang-Undang Nomor 25 Tahun 2004 tentang Sistem Perencanaan Pembangunan Nasional, undang-undang tersebut mendukung penuh akan adanya partisipasi masyarakat, yang menyatakan bahwa Sistem Perencanaan Pembangunan Nasional bertujuan untuk:

a. Mendukung koordinasi antar pelaku pembangunan.

b. Menjamin terciptanya integrasi, sinkronisasi, dan sinergi baik antar daerah, antar fungsi pemerintah maupun antara Pusat dan Daerah.

c. Menjamin keterkaitan dan konsistensi antara perencanaan, penganggaran, pelaksanaan, dan pengawasan.

d. Mengoptimalkan partisipasi masyarakat. 
e. Menjamin tercapainya penggunaan sumber daya alam secara efisien, efektif, berkeadilan, dan berkelanjutan.

Menurut Inu Kencana Syafiie, partisipasi adalah penentuan sikap dan keterlibatan hasrat setiap individu dalam situasi dan kondisi organisasinya, sehingga pada akhirnya mendorang individu tersebut untuk berperan serta dalam pencapaian tujuan organisasi, serta ambil bagian dalam setiap pertanggungjawaban bersama (Syafiie, 200). Serupa dengan apa yang dikemukakan oelh Rahardjo, bahwa Parisipasi masyarakat dapat didefinisikan sebagai keterlibatan dan pelibatan anggota masyarakat dalam pembangunan, meliputi kegiatan dalam perencanaan dan pelaksanaan (implementasi) program pembangunan (Adisasmita, 2006).

Partisipasi masyarakat adalah keikutsertaan masyarakat dalam proses pengidentifikasian masalah dan potensi yang ada di masyarakat, pemilihan dan pengambilan keputusan tentang alternatif solusi untuk menangani masalah, pelaksanaan upaya mengatasi masalah dan keterlibatan masyarakat dalam proses pengevaluasi perubahan yang terjadi (Adi, 2007). Menurut Dwiningrum, partisipasi masyarakat menekankan pada partisipasi langsung warga dalam pembuatan kebijaksanaan dan pengambilan keputusan pada lembaga dan proses kepemerintahan yang mempengaruhi kehidupan warga masyarakat. Partisipasi masyarakat sebagai keterlibatan proaktif dan reaktif terhadap pembangunan dan pelaksanaan program, dengan melakukan sebuah kesepakatan, tindakan dan pembagian kewenangan dan tanggung jawab dalam kedudukan yang setara (Dwiningrum, 2015).

Melaksanakan partisipasi, ada tiga unsur penting yang harus diperhatikan, yaitu: Pertama, partisipasi, keikutsertaan dan keterlibatan sesungguhnya merupakan suatu keterlibatan mental dan perasaan, lebih dari semata-mata atau hanya keterlibatan secara jasmani. Kedua, kesediaan memberi sesuatu sumbangan kepada usaha untuk mencapai tujuan kelompok. Ketiga, tanggungjawab, unsur ini merupakan segi yang menonjol sebagai menjadi anggota atau bagian dari kelompok (Apriyani, 2012).

Bentuk partisipasi dapat dikelompokan menjadi dua jenis, yaitu bentuk patisipasi yang diberikan dalam bentuk nyata dan bentuk patisipasi yang diberikan dalam bentuk tidak nyata. Bentuk partisipasi yang nyata berupa uang, harta benda, tenaga dan keterampilan, sedangkan bentuk partisipasi yang tidak nyata adalah partisipasi buah pikiran, partisipasi sosial, pengambilan keputusan dan partisipasi representatif (Firmansyah, 2019). Partisipasi yang dikemukakan oleh effendi juga terbagi menjadi dua bentuk, yaitu partisipasi vertikal dan partisipasi horizontal. Partisipasi vertikal terjadi dalam kondisi tertentu masyarakat atau mengambil bagian dalam suatu program pihak lain, dalam hubungan dimana masyarakat berada sebagai status bawahan, pengikut, atau klien. Sedangkan partisipasi horizontal, masyarakat mempunya prakarsa dimana setiap anggota atau kelompok masyarakat berpartisipasi horizontal satu dengan yang lainnya (Dwiningrum, 2015).

Menurut Yadav yang dikutip Totok Mardiyanto , ada beberapa bentuk partisipasi yang diberikan maysarakat dalam tahap pembangunan, yaitu (Madiyanto, 2015):

a. Partisipasi Dalam Mengambil Keputusan

b. Partisipasi Dalam Pelaksanaan Kegiatan

c. Partisipasi Dalam Pemanfaatan Evaluasi Pembangunan

d. Partisipasi Dalam Pemanfaatan Hasil Pembangunan

Menurut Santosa dan Heroepoetri, manfaat dari partisipasi masyarakat yaitu sebagai berikut (Santoso, 2005):

a. Menuju masyarakat yang lebih bertanggung jawab.

b. Meningkatkan proses belajar.

c. Mengeliminir perasaan terasing.

d. Menimbulkan dukungan dan penerimaan dari rencana Pemerintah.

e. Menciptakan kesadaran politik.

f. Keputusan dari hasil partisipasi mencerminkan kebutuhan dan keinginan masyarakat.

g. Menjadi sumber dari informasi yang berguna

\section{Pengaturan mengenai Partisipasi Masyarakat dalam Pembentukan Peraturan Desa}

Partisipasi masyarakat dalam pembentukan peraturan perundang-undangan di atur dalam beberapa regulasi, berikut beberapa peraturan perundang-undangan yang mengatur tentang hal tersebut yaitu:

a. Undang-Undang Nomor 12 Tahun 2011 tentang Pembentukan Peraturan Perundang-undangan

Mengenai partisipasi masyarakat di atur dalam Pasal 69 Undang-Undang Nomor 12 Tahun 2011 tentang Pembentukan Peraturan Perundang-undangan menyatakan bahwa:

1) Masyarakat berhak memberikan masukan secara lisan dan/atau tertulis dalam Pembentukan Peraturan Perundang-undangan. 
2) Masukan secara lisan dan/atau tertulis sebagaimana dimaksud pada ayat (1) dapat dilakukan melalui:

a. rapat dengar pendapat umum;

b. kunjungan kerja;

c. sosialisasi; dan/atau

d. seminar, lokakarya, dan/atau diskusi.

3) Masyarakat sebagaimana dimaksud pada ayat (1) adalah orang perseorangan atau kelompok orang yang mempunyai kepentingan atas substansi Rancangan Peraturan Perundang-undangan.

4) Untuk memudahkan masyarakat dalam memberikan masukan secara lisan dan/atau tertulis sebagaimana dimaksud pada ayat (1), setiap Rancangan Peraturan Perundangundangan harus dapat diakses dengan mudah oleh masyarakat.

b. Undang-Undang Nomor 6 Tahun 2014 Tentang Desa

Di atur dalam Pasal 69 ayat (9) yang menyebutkan bahwa "Rancangan Peraturan Desa wajib dikonsultasikan kepada masyarakat Desa". Pasal 69 Ayat (10) menyatakan Masyarakat Desa berhak memberikan masukan terhadap Rancangan Peraturan Desa. Artinya berdasarkan pernyataan dari undang-undang ini dapat penulis simpulkan bahwasannya pembentukan Peraturan Desa mewajibkan adanya konsultasi dengan masyarakat setempat.

c. Peraturan Pemerintah Nomor 43 Tahun 2014 tentang Peraturan Pelaksanaan Undang-Undang Nomor 6 Tahun 2014 tentang Desa

Dalam Peraturan Pemerintah ini tercantum dalam Pasal 83 ayat (3) nya disebutkan bahwa: Dalam Rancangan peraturan Desa sebagaimana dimaksud pada ayat (1) dan ayat (2) wajib dikonsultasikan kepada masyarakat Desa untuk mendapatkan masukan.

d. Peraturan Menteri dalam Negeri Nomor 111 Tahun 2014 tentang Pedoman Teknis Peraturan di Desa

Pasal 13 tentang penyebarluasan menyebutkan bahwa:

1) Penyebarluasan dilakukan oleh Pemerintah Desa dan BPD sejak penetapan rencana penyusunan rancangan Peraturan Desa, penyusunan Rancangan Peratuan Desa, pembahasan Rancangan Peraturan Desa, hingga Pengundangan Peraturan Desa.

2) Penyebarluasan sebagaimana dimaksud pada ayat (1) dilakukan untuk memberikan informasi dan/atau memperoleh masukan masyarakat dan para pemangku kepentingan.

3. Partisipasi Masyarakat dalam Proses Pembentukan Peraturan Desa di Desa Koto Masjid, Kecamatan XIII Koto Kampar, Kabupaten Kampar

Di Desa Koto Masjid Kecamatan XIII Koto Kampar, Kabupaten Kampar tingkat partisipasi masyarakat masih sangat rendah. Partisipasi masyarakat disampaikan melalui Badan Permusyawaratan Desa, artinya selaku pejabat di daerahnya Badan Permusyawaratan Desa dituntut untuk lebih aktif dan memahami pentingnya partisipasi masyarakat.

Aspirasi masyarakat dapat berupa masukan dan sumbang pemikiran, karena keluhan dan pendapat masyarakat akan menjadi pertimbangan dalam pengambilan keputusan. Ketika melakukan penyuluhan langsung, penulis menemukan masih sangat banyak penyelenggara desa (Kepala Desa dan Badan Permusyawaratan Desa) dan masyarakat desa yang belum memiliki pengetahuan dan keahlian dalam bidang peraturan perundang-undangan khususnya dalam pembuatan Peraturan Desa. Tentunya kondisi ini akan berpotensi mempengaruhi kesuksesan implementasi undang-undang tentang Desa, dan bahkan tidak menutup kemungkinan akan menimbulkan kekisruhan hukum, misalnya terjadi pertentangan dan tumpang-tindih peraturan perundang-undangan.

Sehingga untuk diperlukan pengetahuan-pengetahuan mengenai pembentukan peraturan perundangundangan yang mampu memberikan pemahaman kepada pihak terkait yakni Kepala Desa dan Badan Permusyawaratan Desa, mampu mendorong masyarakat untuk berpartisipasi dalam pembentukan peraturan desa, mewujudkan Peraturan Desa yang aspiratif, responsif, taat asas, selaras, dan serasi secara vertikal dan horizontal dalam rangka pembangunan sistem hukum nasional berdasarkan Undang-Undang Dasar Negara Republik Indonesia Tahun 1945, dan menghasilkan Rancangan Peraturan Perundang-undangan yang dapat dipertanggungjawabkan secara filosofis, yuridis, dan sosiologis.

Pengetahuan-pengetahuan tersebut dapat diperoleh melalui penyuluhan-penyuluhan hukum, khususnya penyuluhan hukum terkait partisipasi masyarakat dalam proses pembentukan peraturan desa di Desa Koto Masjid, Kecamatan XIII Koto Kampar, Kabupaten Kampar. 


\section{KESIMPULAN}

Partisipasi masyarakat menekankan pada partisipasi langsung warga dalam pembuatan kebijakaan dan pengambilan keputusan pada lembaga dan proses kepemerintahan yang mempengaruhi kehidupan warga masyarakat. Dalam pembentukan Peraturan Desa masyarakat bisa menyampaikan aspirasinya kepada Badan Permusyawaratan Desa. Akan tetapi masih sangat banyak penyelenggara desa (Kepala Desa dan Badan Permusyawaratan Desa) dan masyarakat desa yang belum memiliki pengetahuan dan keahlian dalam bidang peraturan perundang-undangan. Sehingga menyebabkan partisipasi masyarakat dalam pembentukan Peraturan Desa juga sangat rendah.

Untuk itu dengan dilakukannya penyuluhan hukum mengenai partisipasi masyarakat dalam proses pembentukan peraturan desa di Desa Koto Masjid, Kecamatan XIII Koto Kampar Kabupaten Kampar mampu memberikan pemahaman kepada pihak terkait yakni Kepala Desa dan Badan Permusyawaratan Desa dan mampu mendorong masyarakat untuk berpartisipasi aktif dalam pembentukan Peraturan Desa. Hal ini secara umum ditujukan kepada seluruh masyarakat Indonesia dan khususnya masyarakat di Desa Koto Masjid, Kecamatan XIII Koto Kampar, Kabupaten Kampar.

\section{DAFTAR PUSTAKA}

Adi, I. R. 2007. Perencanaan Partisipsi Berbasis Aset Komoditis, dari Pemikiran Menuju Penerapan. FISIP UI Press. Depok.

Adisasmita, R. 2006. Pembangunan Pedesaan dan Perkotaan. Graha Ilmu. Yogyakarta.

Agustyarna, W. 2014. Proses Penyusunan Peraturan Desa (Studi Kasus Di Desa Penganten Kecamatan Klambu Kabupaten Grobogan Berdasarkan Undang-Undang Nomor 6 Tahun 2014). Naskah Publikasi, Fakultas Keguruan Dan Ilmu Pendidikan Universitas Muhammadiyah Surakarta.

Apriyani, R. 2012. Partisipasi Masyarakat Dalam pelestarian Hutan Mangrove Di Desa Eretan Kulon Kecamatan Kandanghaur Kabupaten Indramayu. Universitas Pendidikan Indonesia. Bandung.

Astawa, I. G. P. 2009. Problematika Hukum Otonomi Daerah di Indonesia. Alumni. Bandung.

Dwiningrum, S. I. A. 2015. Desentralisasi dan Partisipasi Masyarakat dalam Pedidikan. Pustaka Pelajar. Yogyakarta.

Firmansyah, S. 2019. Sosial dan Budaya: Partisipasi Masyakat. Makalah. 5 Juni. diakses dari https://sacafirmansyah.wordpress.com/2009/06/05/partisipasi-masyarakat/ Diakses pada tanggal 21 Juli 2019, pukul 11:17 WIB.

Hamzah, H. \& K. Redindo. 2009. Cara Praktis Menyusun dan Merancang Peraturan Daerah. Kencana Media Group. Jakarta.

Haw, W. 2002. Otonomi Daerah dan daerah Otonom. PT Raja Grafindo Persada. Jakarta.

Hermansyah. 2015. Peran Kepala Desa Dalam Pelaksanaan Pembangunan Kecamatan Tana Lia Kabupaten Tana Tidung (Studi Kasus di Desa Tanah Merah dan Desa Sambungan). eJournal Pemerintahan Integratif, 3(2),351362 ISSN 0000-0000, ejournal.pin.or.id diunduh tanggal 7 Desember 2016

Huda, N. \& Nazriyah. 2011. Teori dan Pengujian Peraturan Perundangundangan. Nusa Media. Bandung.

Kadar, P., A. A. Nasihuddin, \& R. A. Riswari. 2017 . Partisipasi Masyarakat Desa Dalam Penyusunan Peraturan Desa. Jurnal Idea Hukum, 3(1), Magister Hukum Fakultas Hukum Universitas Jenderal Soedirman.

Mardiyanto, T., \& P. Soebiato. 2015. Pemberdayaan Masyarakat dalam Perspektif Kebijakan Publik. Edisi Revisi. Alfabeta. Bandung.

Peraturan Pemerintah Nomor 43 Tahun 2014 tentang Peraturan Pelaksanaan Undang-Undang Nomor 6 Tahun 2014 tentang Desa

Peraturan Menteri dalam Negeri Nomor 111 Tahun 2014 tentang Pedoman Teknis Peraturan di Desa

Peraturan Menteri Desa Pembangunan daerah Tertinggal dan Transmigrasi Republik Indonesia Nomor 3 Tahun 2015 Tentang Pendamping Desa.

Santoso, A. \& Heroepoetri A. 2005. Peran Serta Masyarakat dalam Pengelolaan Keuangan Daerah (Perspektif Hukum Dan Demokrasi). PT. Alumni. Bandung. 
Sofyan. 2014. Partisipasi Masyarakat Dalam Proses Penyusunan Peraturan Desa Di Desa Toapaya Selatan Kecamatan Toapaya Kabupaten Bintan. Skripsi. Program Studi Ilmu Pemerintahan Fakultas Ilmu Sosial Dan Ilmu Politik Universitas Maritim Raja Ali Haji Tanjung Pinang.

Suantra, I. N, \& I. K. P. Sudibya. 2016. Partisipasi Masyarakat Dalam Pembentukan Peraturan Desa Dari Perspektif Good Village Governance. Laporan Penelitian, Program Studi Ilmu Hukum Fakultas Hukum Universitas Udayana Denpasar, Hlm. 2.

Syafiie, I. K. 2002. Sistem Pemerintahan Indonesia. PT. Rineka Cipta. Jakarta.

Undang-Undang Nomor 25 Tahun 2004 tentang Sistem Perencanaan Pembangunan Nasional.

Undang-Undang Nomor 12 Tahun 2011 tentang Pembentukan Peraturan Perundang-undangan.

Undang-Undang Nomor 6 Tahun 2014 Tentang Desa.

Undang-Undang Nomor 9 Tahun 2015 tentang Perubahan Kedua Atas Undang-Undang Nomor 23 Tahun 2014 tentang Pemerintahan Daerah. 